DOI: https://doi.org/10.24867/13BE11Vukovic

\title{
ПРИМЈЕНА СОФТВЕРСКИХ АЛАТА ЗА ПРОРАЧУН НАПАЈАНА СОЛАРНОМ ЕНЕРГИЈОМ КУЋЕ У ДВОРОВИМА
}

\section{SOFTWARE TOOLS APLICATION IN CALCULATION OF SOLAR ENERGY POWER SUPPLY FOR THE HOUSE IN DVOROVI}

\author{
Зоран Вуковић, Владимир Катић, Факултет техничких наука, Нови Сад
}

\begin{abstract}
ОбЛасТ - ЕЛЕКТРОТЕХНИКА И РАЧУНАРСТВО
Кратак садржај - У раду је уопштено речено о обновљивим изворима енергије и юиховој подјели. Након тога је дат већи значај соларног енергији и фотонапонским соларним системима. Израчуната је производња соларне електране и упоређена са потрошњом домаћинства. Одрађен је модел фотонапонске електране у матлаб Симулинк окружењу уз помоћ којег су добијени одзиви произведене снаге. Извриена је дискусија резултата, гдје су упоређени резултати добијени мјерењем и симулацијом.
\end{abstract}

Кључне ријечи: Соларна електрана, Фотонапонски системи, Соларни панели

\begin{abstract}
In this work it has been generally said something about renewable energy sources and their division. After that bigger importance has been given to solar energy and photovoltaic solar systems. Production of solar power plant has been calculated and compared with the household consumption. The model of photovoltaic power plant has been done in Matlab Simulink, by which the response of produced power has been gained. The discussion about the results has been led and the results gained by measurements and simulations have been compared.
\end{abstract}

Keywords: Solar power plant, Photovoltaic systems, Solar panels

\section{1. УВОД}

Обновљиви извори енергије подразумијевају изворе енергије који се налазе у природи и који се обнављају у цјелости или дјелимично, посебно енергија водотокова, вјетра, неакумулирана сунчева енергија, биомаса, биомаса животињског поријекла, геотермална енергија, биогорива, биогас, синтетички гас, депонијски гас, гас из постројења за третман комуналних вода и отпадних вода из прехрамбене и дрвно - прерађивачке индустрије које не садрже опасне материје. Обновљиви извори енергије се користе за производњу електричне, механичке и топлотне енергије.

Фотонапонски (ФН) соларни системи раде на принципу фотонапонске конверзије сунчевог зрачења која се врши у соларним, ФН ћелијама које се израђују од полупроводничких материјала.

\section{НАПОМЕНА:}

Овај рад проистекао је из мастер рада чији ментор је био др Владимир Катић, ред. проф.
ФН систем подразумијева систем помоћу кога се врши снабдијевање једносмјерном (DC), наизмјеничном (AC) или и једносмјерном и наизмјеничном струјом. Системи на којима се врши конверзија сунчевог зрачења и у електричну и у топлотну енергију се називају мултифункционални или хибридни системи. ФН ћелија је полупроводнички склоп који врши конверзију соларне у електричну енергију, односно сунчевог зрачења у једносмјерну струју.

Максимални излазни напон једне соларне ФН ћелије се креће у опсегу 0,6 V - 0,7 V. Међутим, приликом рада, генерисана струја производи пад напона на унутрашњој отпорности ћелије, тако да се номинални напон креће између $0,4 \mathrm{~V}$ и 0,5 V. Према пројектованом излазном напону и снази ФН ћелије се везују редно у модуле, а они даље редно и/или паралелно у ФН панеле. Излазни напон ФН панела прати потребе примјене, односно формира се тако да одговара неком једносмјерном (DC) систему или акумулатору, односно да буде погодан за рад инвертора (DC/AC претварача) у случају прикључења на мрежни (AC) систем [1].

\section{2. СОФТВЕРСКИ АЛАТИ ЗА МОДЕЛОВАЊЕ И АНАЛИЗУ ФОТОНАПОНСКИХ ЕЛЕКТРАНА}

За моделовање и анализу ФН електрана постоји већи број софтверских алата [2]. У овом раду биће коришћени и описани неки од њих, односно:

- PVGIS (Photovoltaic Geographical Information System),

- Homer Pro (Hybrid Optimization of Multiple Electric Renewables), и

- Matlab (MATrix LABoratory).

\subsection{PVGIS (Photovoltaic Geographical Information} System)

Овај софтверски алат служи за процјену производње електричне енергије самосталног ФН система или ФН система прикљученог на мрежу. Суштина софтвера је да покаже какав утицај има изабрана локација на планирање ФН система, као и база података о сунчевом зрачењу на тој локацији за дужи временски период. Помоћу PVGIS-а могуће је израчунати колико енергије се може добити из различитих врста ФН система на готово било ком мјесту на свијету [3].

2.2. Homer Pro

Homer Pro омогућава ручно или аутоматски, путем унесених координата мјеста, одређивање података о сунчевој радијацији, температури, брзини вјетрова, 
итд. Након тога се у софтверу формира модел за који се жели направити симулација.

На основу модела и унесених података о сунчевој радијацији и параметара (оптерећења, ФН панела и конвертора) можемо добити симулацију рада система и приказ укупне годишње производње и потрошње енергије [4].

\subsection{Matlab/Simulink}

Матлаб је виши програмски језик намјењен обради података у форми матрица и бројева. Сам назив Матлаб изведен је од MATrix LABoratory (лабораторија за матрице), чиме се сугерише да су матрице основни ентитети за нумеричке прорачуне, за разлику од неких нижих програмских језика као што је Fortran или Pascal.

Симулинк је графичко програмско окружење засновано на Матлабу за моделовање, симулацију и анализу вишедоменских динамичких система [5].

\section{3. ОПИС ОБЈЕКТА И ЕНЕРГЕТСКЕ КАРАКТЕРИСТИКЕ}

Објекат (кућа), који је потребно напајати из ФН панела, налази се у мјесту Дворови (БИХ) на свега 3 $\mathrm{km}$ од Бијељине, у сјевероисточном дијелу Републике Српске, у Семберији, равничарској области између Посавине, Подриња, Срема, Мачве и мајевичког подбрђа.

Дворови се налазе у средишту између ријека Саве и Дрине и путева који преко Раче и Павловић моста из Србије воде у Бијељину и даље до Бања Луке и Источног Сарајева.

\section{1. Годишња потрошња електричне енергије}

У објекту се налазе стандардни кућни апарати, системи гријање, климатизације и још неки додатни неопходни електрични апарати и уређаји. У табели 1. je приказана потрошња електричне енергије по мјесецима. Ако се претпостави да просјечни однос потрошње више и ниже тарифе износи $70 \%$ на према $30 \%$, и чињеница да су дужина трајања зимске и љетне сезоне подједнаки, долази се до просјечне цијене ел. енергије по kWh од 0,1116 KM, чиме се могу израчунати и месечни, односно годишњи трошкови за електричну енергију.

\section{2. Енергетске карактеристике}

На основу програма PVGIS добија се да је соларни енергетски потенцијал на локацији објекта у Дворовима такав да се из $1 \mathrm{kWp} Ф Н$ панела нагнутог под углом $30^{\circ}$ према југу, уз уважавање $14 \%$ електричних губитака у водовима и инвертору, може добити $1.197 \mathrm{kWh}$ електричне енергије.

Да би се покрила годишња потрошња објекта, потребно је инсталирати $6.796 \mathrm{kWh} / 1.197 \mathrm{kWh}$, односно соларну ФН електрану излазне снаге $5,7 \mathrm{~kW}$. С обзиром да се снага укупна панела узима 10\%-20\% већа од излазне снаге, а да је просечна површина једног ФН панела снага 240-290 Wp око 1,62 $\mathrm{m}^{2}$, произилази да би за такву кровну ФН електрану требало од $38,2 \mathrm{~m}^{2}$ до 46,2 $\mathrm{m}^{2}$ кровне површине.
Табела 1. Годишьа потрошьа електричне енергије по мјесеиима

\begin{tabular}{|c|c|c|}
\hline Мјесец & $\begin{array}{c}\text { Потрошња } \\
(\mathbf{k W h})\end{array}$ & Уплата (KM) \\
\hline Јануар & 606 & 67.62 \\
\hline Фебруар & 547 & 61.05 \\
\hline Март & 579 & 64.61 \\
\hline Април & 583 & 65.06 \\
\hline Мај & 552 & 61.60 \\
\hline Јун & 517 & 57.69 \\
\hline Јул & 572 & 63.83 \\
\hline Август & 567 & 63.27 \\
\hline Септембар & 601 & 67.08 \\
\hline Октобар & 537 & 59.93 \\
\hline Новембар & 525 & 58.59 \\
\hline Децембар & 610 & 68.07 \\
\hline Годишња & $\mathbf{6 . 7 9 6}$ & $\mathbf{7 5 8 . 4}$ \\
\hline потрошња & & \\
\hline
\end{tabular}

\section{4. ИДЕЈНО РЈЕШЕЊЕ НАПАЈАЊА ЕЛЕКТРИЧНОМ ЕНЕРГИЈОМ ПРЕКО СОЛАРНИХ ПАНЕЛА}

\section{1. Прорачун могуће снаге кровне ФН електране}

За прорачун могуће снаге електране и одређивање броја панела који се могу монтирати на кров куће (објекта) користи се онлајн алат Base K2 Systems. To је алат за пројектовање развијен од стране њемачке фирме K2 Systems која се бави производњом и продајом носећих конструкција за соларне панеле [6].

Приликом пројектовања кућног фотонапонског система за изабрани соларни панел Benq SUNVIVO PM060MW2, онлајн алат Base K2 Systems je на основу задатих димензија крова одредио да је могуће поставити максимално 44 панела.

Снага кровне електране би била између:

$$
\begin{aligned}
& P_{\text {min }}=P_{\text {panela } \min } \cdot N_{\text {panela }}=240 \mathrm{~W}_{p} \cdot 44=10,56 \mathrm{~W}_{\mathrm{p}}(1) \\
& P_{\text {max }}=P_{\text {panela } \max } \cdot N_{\text {panela }}=290 \mathrm{~W}_{p} \cdot 44=12,76 \mathrm{~W}_{p}(2)
\end{aligned}
$$

Инвертор који одговара овом прорачуну треба да задовољи око $80 \%$ - $90 \%$ укупне снаге соларних панела.

Поређењем овог и резултата из подпоглавља 3.2, може се констатовати да је на кров могуће сместити ФН електрану, која је оквирно двоструко веће снаге од енергетских потреба објекта.

С обзиром на променљивост сунчевог зрачења и одређену несигурност таквог напајања, инсталирање и тако увећаног капацитета се може оправдати.

\section{2. Идејно рјешење кровне ФН електране}

Како је већ речено на кров куће може стати 44 ФН панела и да ће снага ФН електране бити $12,76 \mathrm{kWp}$. Идеја је да се формирају 4 ФН низа (стринга) и да се сваки од низова састоји од 11 панела чиме се добија ФН електрана од 44 соларна панела. 


\section{3. Годишња производња електричне енергије} добијена преко софтверског алата PVGIS

Софтвер PVGIS је описан у подпоглављу 2.1 при чему га сада користимо да бисмо одредили укупну производњу електричне енергије соларне електране, која је приказана у табели 2.

Табела 2. Годишња производња електричне енергије ФH система по мјесеиима према PVGIS [3]

\begin{tabular}{|c|c|c|}
\hline Мјесец & $\mathbf{E m}$ & $\mathbf{H m}$ \\
\hline Јануар & 613 & 58.57 \\
\hline Фебруар & 666.76 & 64.58 \\
\hline Март & 1206.49 & 121.46 \\
\hline Април & 1489.20 & 155.94 \\
\hline Мај & 1622.07 & 173.65 \\
\hline Јун & 1671.54 & 181.93 \\
\hline Јул & 1843.76 & 203.68 \\
\hline Август & 1734.73 & 190.8 \\
\hline Септембар & 1372.78 & 145.79 \\
\hline Октобар & 1112.44 & 113.24 \\
\hline Новембар & 800.60 & 78.08 \\
\hline Децембар & 539.29 & 51.75 \\
\hline $\begin{array}{c}\text { Укупно } \\
\text { годишње }\end{array}$ & $\mathbf{1 4 6 7 2}$ & $\mathbf{1 5 3 9}$ \\
\hline
\end{tabular}

Легенда: $E m$ - просјечна мјесечна производња електричне енергије у разматраном систему (kWh); $\mathrm{Hm}$ - просјечна мјесечна сума зрачења глобалне радијације коју прима модул разматраног система $\left(\mathrm{kWh} / \mathrm{m}^{2}\right)$

\section{5. МОДЕЛ ФН ЕЛЕКТРАНЕ У МАТЛАБУ}

Модел $Ф Н$ електране чине четири низа $Ф Н$ панела повезана на заједнички инвертор (слика 1). Инвертор је управљан импулсно - ширинском модулацијом, а излазни напон је преко једноставног филтра повезан на мрежу. Мрежа је представљена преко импедансног модела.

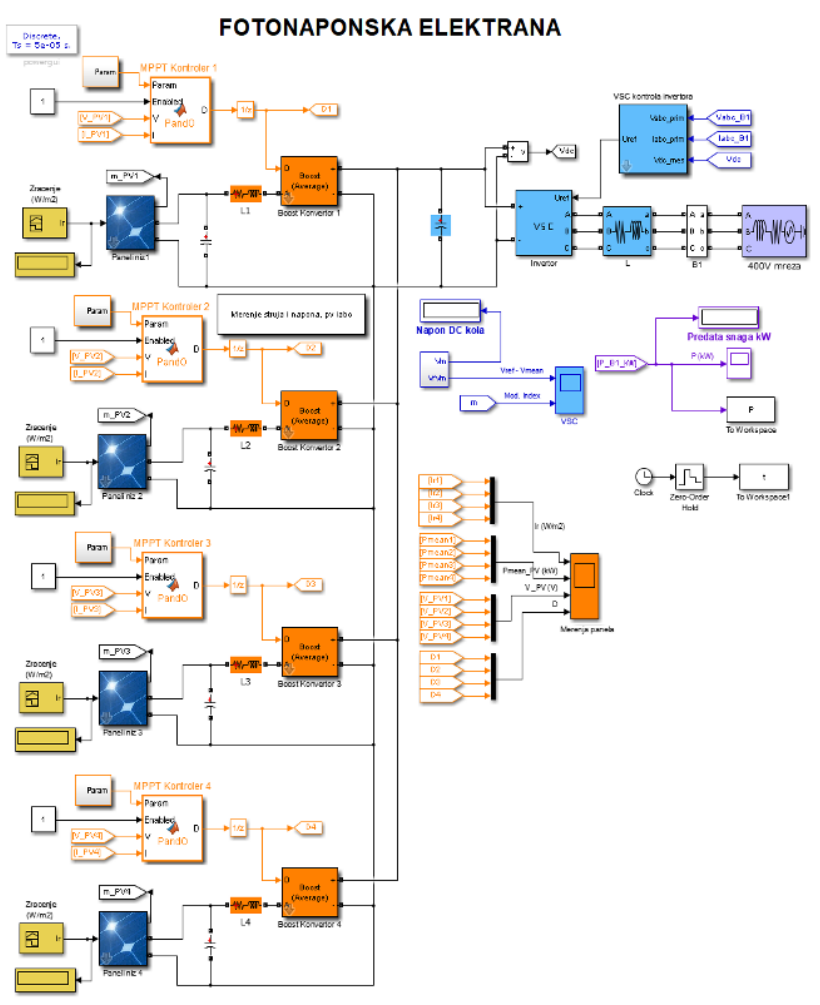

Слика 1. Комплетан Симулинк модел ФН електране
Први низ ФН панела је означен у моделу као блок „Панели низ 1“. У том блоку су наведени подаци о панелима као и броју панела коју низ садржи. На овај блок су повезани подаци о сунчевом зрачењу који су означени као „Зрачење $\left(\mathrm{W} / \mathrm{m}^{2}\right)^{\text {“. }}$. У њему ће бити задато сунчево зрачење у току једног дана за сва четири годишња доба.

\section{6. СИМУЛАЦИЈА ДНЕВНОГ РАДА ФН ЕЛЕКТРАНЕ}

\section{1. Одзиви све четири соларна низа при промјенљивој радијацији}

На слици 2. приказан је одзив снаге ФН електране који је добијен на основу задате промјенљиве радијације за један дан у јуну. Како радијација почиње да расте у јутарњим часовима тако почиње и производња снаге. Највећа производња снаге биће у послијеподневним часовима

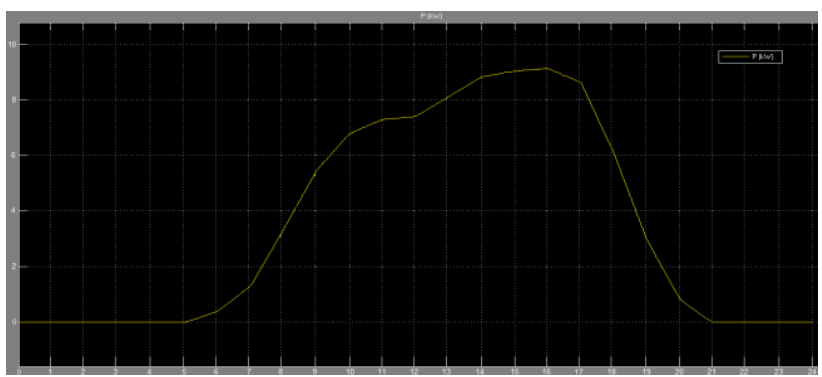

Слика 2. Одзиви снаге ФН електране за један дан у јуну

На слици 3. приказан је одзив снаге ФН електране који је добијен на основу задате промјенљиве радијације за по један дан у септембру и марту. Разлог што су на истом графику приказани одзиви за ова два мјесеца лежи у томе што у овим мјесецима (прољеће и јесен) владају приближно исте временске прилике са истим интензитетом сунчевог зрачења. На слици 4. приказан је дијаграм промјене снаге за један дан у децембру.

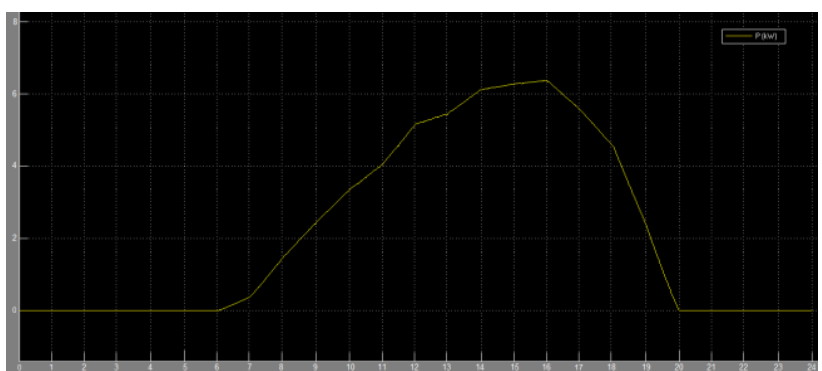

Слика 3. Одзиви снаге ФН електране за један дан у септембру и марту

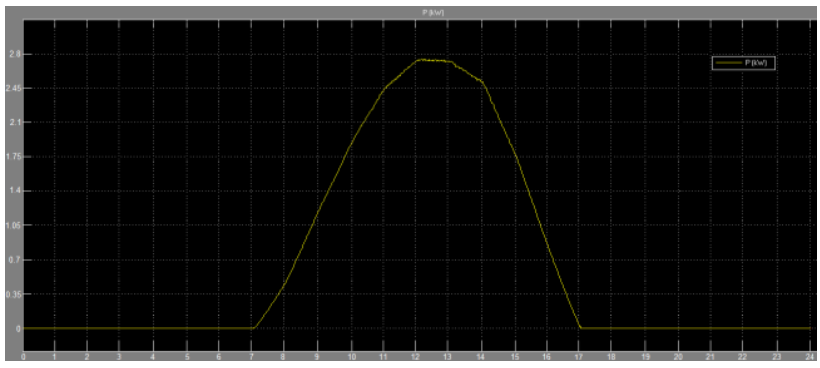

Слика 4. Одзиви снаге ФН електране за један дан у децембру 


\section{2. Генерисање дневних дијаграма за производњу соларне електране}

На сљедећа три дијаграма $(5,6,7)$ приказана је произведена снага соларне електране на дневном нивоу за четири годишња доба, добијена помоћу софтверског алата PVGIS. У разматрање су узети по један дан из децембра, марта, јуна и септембра чиме су обухваћена све четири годишња доба.

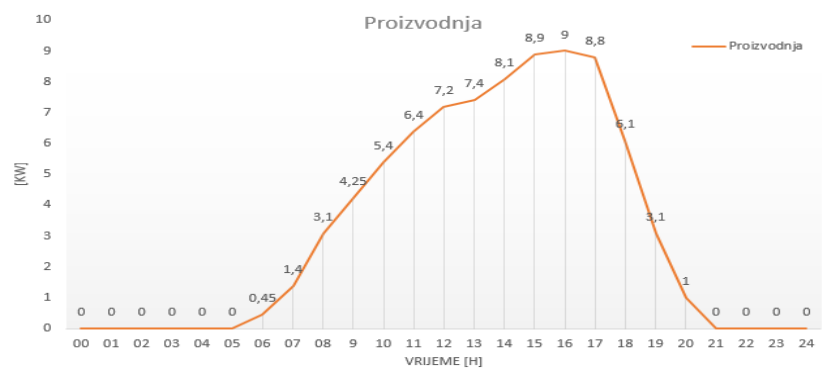

Слика 5. Графички приказ произведене снаге добијене помоћу PVGIS-a за један дан у јуну

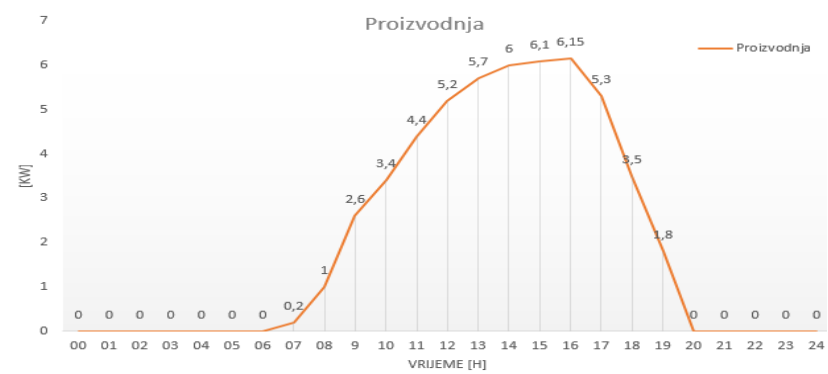

Слика 6. Графички приказ произведене снаге добијене помоћу PVGIS-а за један дан у септембру и марту

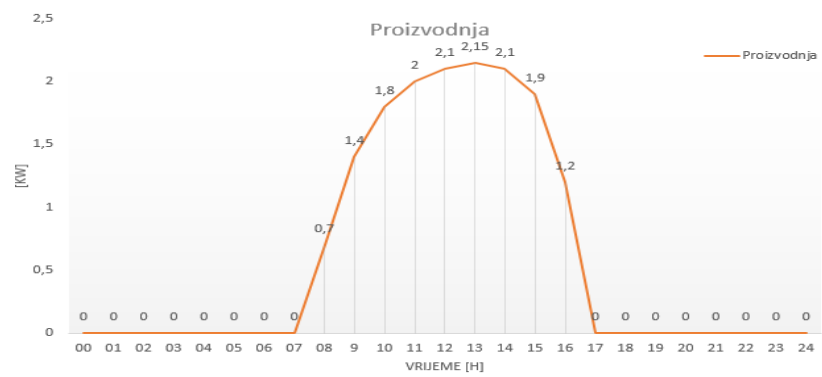

Слика 7. Графички приказ произведене снаге добијене помоћу PVGIS-а за један дан у децембру

\section{3. Поређење и дискусија}

Визуелним поређењем симулираних резултата и резултата добијених помоћу PVGIS-a може се уочити велика сагласност. Да би се ово запажање потврдило, израчуната је разлика у вриједностима добијена симулацијом и вриједностима добијених из софтверског алата PVGIS за свако годишње доба и представљена у табели 3. Види се да су и апсолутна и релативна грешке прихватљиве, тј. да је модел $Ф Н$ електране прихватљив.

Табела 3. Поређење резултата

\begin{tabular}{|c|c|c|c|}
\hline & Љето & Прољеће/Јесен & Зима \\
\hline$\Delta \mathrm{x}$ & 0,27 & 0,13 & 0,06 \\
\hline$\delta$ & 4,78 & 3,18 & 3,65 \\
\hline
\end{tabular}

Легенда: $\Delta \mathrm{x}$ - апсолутна грешка мјерења $(\mathrm{kW}) ; \delta$ - релативна грешка мјерења (\%)

\section{4. Рад фотонапонске електране при промјенљивим временским условима}

На слици 8. приказан је одзив снаге ФН електране при промјенљивим временским условима када у току дана постоје велика наоблачења, која често заклањају сунце и тако праве већу сјенку за ФН електрану.

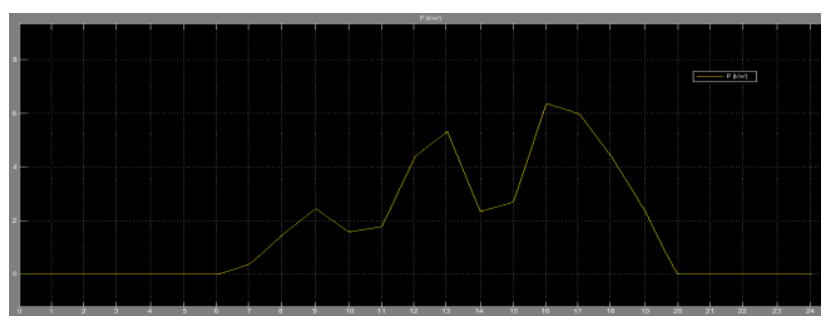

Слика 8. Одзив снаге при промјенљивим условима

\section{7. ЗАКЉУЧАК}

Циљ рада је био да се прикаже колико је реално извести један овакав пројекат у којем би се поставили соларни панели на кров куће у Дворовима. Рад се највише базира на моделовању и анализирању ФН електране примјеном савремених софтверских алата. Анализирано је понашање ФН електране за све четири годишња доба.

Производња ФН електране ће бити највећа у љетним мјесецима при јачем интензитету сунчевог зрачења. Модел је верификован поређењем са резултатима мерења.

\section{8. ЛИТЕРАТУРА}

[1] Ч. Зељковић, „Обновљиви извори енергије соларна енергетика“, Универзитет у Бањој Луци и Академска мисао, Бања Лука и Београд, 2018.

[2] А. Гавриловић, В. Катић, „Преглед расположивих софтвера за соларне електране“, Зборник радова Факултета техничких наука, Нови Сад, Год. 34, Бр. 3, 2019.

[3] https://ec.europa.eu/jrc/en/PVGIS/docs/starting

[4] https://www.homerenergy.com

[5] https://www.mathworks.com

[6] https://k2-systems.com/en/base-3

\section{Кратка биографија:}

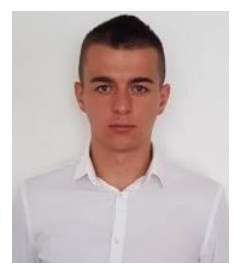

Зоран Вуковић рођен је у Доњем Вакуфу 1994. год. Факултет техничких наука, студијски програм Енергетика, електроника и телекомуникације уписао je 2013. год. Дипломирао је 2018. год, након чега је уписао мастер студије на смјеру „Електроенергетика - Енергетска електроника и електричне машине“.

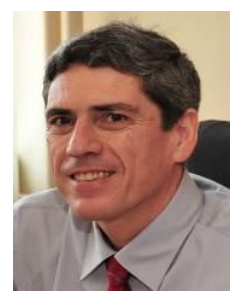

Владимир Катић рођен је 1954. год. у Новом Саду. Докторирао је на Универзитету у Београду 1991. год. Од 2002. је редовни професор Универзитета у Новом Саду. Области интересовања су енергетска електроника, обновљиви извори електричне енергије, електрична возила и квалитет електричне енергије. 